\title{
Is there any Effect of Blood Glucose Level on Finger Biting?
}

\author{
Qadir MI and Qureshi HN* \\ Institute of Molecular Biology and Biotechnology, Bahauddin Zakariya University, \\ Pakistan
}

*Corresponding author: Hira Naeem Qureshi, Institute of Molecular Biology and

\section{Research Article}

Volume 2 Issue 1

Received Date: May 04, 2019

Published Date: May 16, 2019

DOI: $10.23880 /$ aabsc-16000122

Biotechnology, Bahauddin Zakariya University, Multan, Pakistan, Email: hiranaeem2306@gmail.com

\section{Abstract}

To interact glucose level of blood with finger biting was the goal of present research. 130 subjects took part in present research, where their glucose level of blood calculated. The normal glucose level in blood is in between 100 to $140 \mathrm{mg} / \mathrm{dl}$. The hyperglycemia is known as high glucose level while hypoglycemia is known as low glucose level. The biting of fingers in the mouth with teeth is known as finger biting. It also refer as onychophagia. There were 130 students take part in this research and they measured their sugar level by using glucose meter. Then they correlate the glucose level with finger biting. It was concluded from the present study that glucose level of blood has no impact on finger biting.

Keywords: Finger Biting; Blood; Sugar Level; Fingers

\section{Introduction}

In humans and animals the concentration of sugar in blood are called glucose and sugar level in blood. In morning the blood glucose level is low but after meals the glucose level rise. The blood sugar level checks after fasting. The normal glucose level in blood is in between 100 to $140 \mathrm{mg} / \mathrm{dl}$. The hyperglycemia is known as high glucose level while hypoglycemia is known as low glucose level. The blood sugar is test by various methods. The blood sugar is measured by blood glucose meter. The hunger, confusion, headaches, dizziness, sweating, disturb pulse rate, weakness, pale skin and anxiety are symptoms of low sugar level. The high glucose level is affecting your blood vessel, nerves and organs like kidney. There are two types of diabetes. If high glucose level is not control its lead to death. The blurred vision, skin and eyes infection, constipation, weight loss, loss of hair, stomach problem, cold, diarrhea are causes of high glucose level [1].
The biting of fingers in the mouth with teeth is known as finger biting. It also refers as onychophagia. The digestive system is affected by finger biting. The tissues of fingers are damages by finger biting. The length of nails is also reduced due to finger biting. The better way to prevent finger biting is nail cosmetics and chewing gum. Mostly children start bites their finger in the age of 4 years. The $50 \%$ children in age 6 to 10 years are usually bite their fingers. The mental and emotional stress, hunger are major cause of finger biting. Finger biting in children is shameful for parents in society. The girls are mostly like to bite their fingers [2]. The aim of the current study was to associate blood oxygen level with finger biting.

\section{Materials and Methods}

The 130 subjects took part in current study. All subjects were students of Bahauddin Zakariya University, Multan, Pakistan. The blood sugar level is measured by blood glucose meter. First you take a small 
drop of blood. Then put this blood sample on the strip of glucose meter. Then insert the strip to glucose meter and calculate the sugar level.

\section{Statistical Analysis}

Statistical analysis was measured by M state. Student's $t$-test was operating to check conclusion of $p$ value. The $p<0.05$ are calculated as significant.

\section{Result and Discussion}

Effect of blood glucose level on finger biting is given in Table 1. The hyperglycemia is known as high glucose level while hypoglycemia is known as low glucose level. 9 males out of 130 subjects are addict of finger biting with means 99 and standard deviation 6.61 while 21 males are not addict of finger biting with means 95.33 and standard deviation 9.06. The $p$ value of males is 0.17 . The 22 females are addict of finger biting with means 90.27 and standard deviation 6.92 while 78 females are not addict of finger biting with means 92.48 and standard deviation 7.56. The $p$ value of females is 0.20 . The total 31 subjects are addict to finger biting with means 90.48 and standard deviation 6.84 while 99 subjects are not addict to finger biting with means 92.95 and standard deviation 8.16. There $p$ value is 0.09 . A questionnaire based studies have been given important outcome in current researches [3$10]$.

\begin{tabular}{|c|c|c|c|}
\hline Gender & People who addict of finger biting & People who don't addict of finger biting & $\boldsymbol{p}$ value \\
\hline Male & $99 \pm 6.61$ & $95.33 \pm 9.06$ & 0.17 \\
\hline Female & $90.27 \pm 6.92$ & $92.48 \pm 7.59$ & 0.2 \\
\hline Both & $90.48 \pm 6.84$ & $92.95 \pm 8.16$ & 0.09 \\
\hline
\end{tabular}

Table 1: Effect of Blood Glucose Level (Means \pm SD) on Finger Biting. Non-Significant $p>0.05$

\section{Conclusion}

It was concluded from present research that glucose level has no impact on finger biting.

\section{References}

1. Karlsson K, Kjellmer I (1972) The outcome of diabetic pregnancies in relation to the mother's blood sugar level. Am J Obstet Gynecoly 112(2): 213-220.

2. Tanaka OM, Vitral RW, Tanaka GY, Guerrero AP, Camargo ES (2008) Nailbiting, or onychophagia: a special habit. Am J Orthod Dentofacial Orthop 134(2): 305-308.

3. Qadir MI, Javid A (2018) Awareness about Crohn's Disease in biotechnology students. Glo Adv Res J Med Medical Sci 7(3): 62-64.

4. Qadir MI, Saleem A (2018) Awareness about ischemic heart disease in university biotechnology students. Glo Adv Res J Med Medical Sci 7(3): 59-61.
5. Qadir MI, Ishfaq S (2018) Awareness about hypertension in biology students. Int J Mod Pharma Res 7(2): 08-10.

6. Qadir MI, Mehwish (2018) Awareness about psoriasis disease. Int J Mod Pharma Res 7(2): 17-18.

7. Qadir MI, Shahzad R (2018) Awareness about obesity in postgraduate students of biotechnology. Int J Mod Pharma Res 7(2): 14-16.

8. Qadir MI, Rizvi M (2018) Awareness about thalassemia in post graduate students. MOJ Immunology 6(5): 163-165.

9. Qadir MI, Ghalia BA (2018) Awareness survey about colorectal cancer in students of M. Phil Biotechnology at Bahauddin Zakariya University, Multan, Pakistan. Nov Appro in Can Study 1(3): 1-5.

10. Qadir MI, Saba G (2018) Awareness about intestinal cancer in university student. Nov Appro in Can Study 1(3): 1-3. 